\title{
Physiological and Histopathological studies on Bisphenol-A compound as xenoestrogen in male albino rats
}

\author{
Eman G.E.Helal *; Mohamed M.M. Badawi **; Maha G. Soliman *; Nadia A. Abdel-Kawi *; Hewaida
}

A. E. Fadel ***; Nashwa M. G. Abozaid .**

Department of Zoology, Faculty of Science, Al-Azhar University (Girls)*; Department of Biochemistry, National organization for Drug Control and Research**. Department of Nutritional Chemistry and Metabolism, National Nutrition Institute ${ }^{* * *}$

\begin{abstract}
Back ground: Xenoestrogens are compounds like estrogens in effect but not in structure which are mimicking the action of endogenous estrogen and activate estrogen receptor. Xenoestrogens are chemically distinct industrial products potentially able to disrupt the endocrine system by mimicking the action of endogenous steroid hormones. Among such compounds, the ubiquitous environmental contaminants bisphenol-A (BPA) may promote adverse effects in humans triggering estrogenic signals in target tissues. Bisphenol- A is widely used in food and drinks packaging.
\end{abstract}

Aim of the work: The present study is carrying out to evaluate the effect of bisphenol-A on sexual hormonal pattern in male albino rats.

Material and Methods: 64adult male Sprague - Dawley rats (100-120 g) were divided to four groups (16 rats/group).Group (1): control group without any treatment. Group(2): positive control group was injected subcutaneously (s.c) with sesame oil daily. Group (3): received BPA daily with low dose (10 mg/kg/day s.c). Group (4): received BPA daily with high dose (30 mg/kg/day s.c). The experiment durated 30 days, half rats of each group were sacrificed after 15 days of treatment and the other half of groups after 30 days. The blood was collected, serum was separated and used for estimation of (hormonal levels, prolactin, gonadotrophin and testosterone) and some biochemical parameters (liver enzymes, kidney function, protein and lipid profile). Testis, liver and kidney were taken for the histopathological examination.

Results: Biochemical results showed significant elevation in prolactin and FSH levels and significant reduction in LH and testosterone levels in all groups compared to the control group. Increased serum enzymes (ASAT, ALAT\& ALP) levels with increased concentration of urea and creatinine were detected in all the treated groups compared to the control group. Decline in protein profile and elevation in the concentration of lipid profile, while HDL was decreased in all the treated groups. Histopathological results showed dystrophic changes in the form of congestion in the blood vessels of the testis, liver and kidney of rats with thickening of walls of the blood vessels especially in the testis. In liver, focal inflammatory areas, with dilated and congested central and portal veins were found. Vacuolar degenerative changes in hepatocytes were seen. In the kidney, mild nephritis, sclerotic changes in glomerular tuft, hyaline casts in the lumen of epithelial cells which lining convoluted tubule were noticed.

Conclusion: From the previous results we concluded that bisphenol-A has dangerous effects on the testis, liver and kidney tissues. Also it disrupted sexual hormonal pattern and affect biochemical and lipid parameters. So, we recommended minimizing the utililizing of these compound to protect people from its hazardous effects.

Key words- Xenoestrogens , Bisphenol-A, Hormonal assay , Biochemical parameters , Histopathological changes.

\section{Introduction:}

Xenoestrogens are small lipophillic molecules that mimic physiological estrogens [1] and whose exposures have been linked to a variety of disease states even when present at concentrations far below those currently allowed by federal regulations[2\&3].

Bisphenol A (BPA) has been acknowledged as an estrogenic chemical able to interact with human estrogen receptors (ER). Many lines of evidence reveal that BPA has an impact as an endocrine disruptor even at low doses. However, it's binding to ER and hormonal activity is extremely weak, making the intrinsic significance of low dose effects obscure. We thus supposed that BPA might interact with nuclear receptor(s) other than ER Bisphenol-A (BPA) is a high production volume chemical used principally as a monomer in the manufacture of numerous chemical products [4]. Bisphenol- A (BPA) is a chemical used for lining metal cans and in polycarbonate plastics, such as baby bottles. In rodents, BPA is associated with early sexual maturation, altered behavior, and 
effects on prostate and mammary glands. In humans, BPA is associated with cardiovascular disease, diabetes, and male sexual dysfunction in exposed workers. Food is a major exposure source

BPA can contaminate the environment in significant amounts by leaching from products (plastic food and water containers, dental sealants, and some cash register receipts), and as byproducts of manufacturing [5].

This study aimed to investigate the influence of Bisphenol-A compound on certain hormonal levels, biochemical parameters in addition to the histopathlogical studies including the testis, liver and kidney tissues.

\section{Material and methods:}

Sixty four adult male Sprague - Dawley rats $(100-120 \mathrm{~g})$ allowed free access to water and standard diet (S.D.) which was prepared according to modified AIN-93-A [6] for one week. The chosen animals were housed in cages and exposed to artificial light for $14 \mathrm{hrs}$ and $10 \mathrm{hrs}$ complete darkness at normal atmospheric temperature. The rats were divided to 4 groups each group consisted of 16 rats. Group (1): control group without any treatment (NC). Group(2): positive control group, rats were injected subcutaneously (s.c) with sesame oil daily (PC). Group (3): received BPA daily with low dose $(10 \mathrm{mg} / \mathrm{kg} /$ day s.c)(BPAL). Group (4): received BPA daily with high dose (30 $\mathrm{mg} / \mathrm{kg} /$ day s.c) (BPAH).

BPA dissolved in sesame oil and injected subcutaneously (s.c.), the dose was calculated according to Takahashi and Oishi [4].

At the end of the experiment, the animals were fasted for about $12 \mathrm{~h}$. before sacrifices. The blood was collected from retro-orbital vein and centrifuged for serum which kept at $-20^{\circ} \mathrm{C}$

The testis, liver and kidney were kept in $10 \%$ formol for the histological study.

Hormonal assay: Serum prolactin, gonadotrophic (FSH-LH) and testosterone were measured by Enzyme-linked Immune Sorbent Assay (ELISA) according to Liu et al. [7], Urban et al. [8], Leviene et al.[9] and Bricaire et al.[10] respectively.

Biochemical parameters: The following parameters were determined: aspartate amino transferase (AST) and alanine amino transferase (ALT) according to [11], serum alkaline phosphatase [12], serum Urea, creatinine, total proteins and albumin were carried out $[13,14 \& 15]$ respectively. Determination of serum total lipids [16], total cholesterol [17], Triglycerides [18], low density lipoprotein (LDL)and high density lipoprotein (HDL)[19], respectively.

Histological staining of the tissues: was carried out according to the method of Drurg and Wallington [20].

Statistical analysis -The results were analyzed statistically using means and standard deviation (SD) by SPSS/PC program V17 .

\section{Results:}

Hormonal levels: In rats treated with sesame oil showed normal biochemical levels and histological pattern compared with the control group. Table (1) showed the effect Bisphenol-A on serum PRL, FSH, LH and T levels of male albino rats in all groups. BPA in low dose $(10 \mathrm{mg} / \mathrm{kg} /$ day $)$ and high dose $(30 \mathrm{mg} / \mathrm{kg} /$ day) caused significant elevation $(\mathrm{P}<0.01)$ in PRL\& FSH levels after 15 and 30 days of administration as compared to the control group. A reversed pattern was apparent for $L H \& T$ values where their levels were significantly decreased $(\mathrm{P}<0.01)$.

Serum enzymes: The data in table (2), showed that treatment with BPA induced significant increase $(\mathrm{P}<0.01)$ in the enzyme activities (ALAT, ASAT and ALP) with low and high doses for both periods of the experiment as compared to the control group.

Kidney function: The data demonstrated that treatment with BPA showed a significant increase $(\mathrm{P}<0.01)$ in serum urea, creatinine, in all the treated groups throughout the experiment as compared to the control rats (Table 3 ).

Table (4) showed that rats received BPA exhibited a significant reduction $(\mathrm{P}<0.01)$ of total protein, albumin and $\mathrm{A} / \mathrm{G}$ ratio levels in all the treated groups throughout the experiment compared to the normal control group. In contrast, serum globulin of rats treated with BPA unaltered with low and high doses after 15 and 30 days in all the studied groups.

Serum lipid profile: table (6) showed, that rats treated with bisphenol-A exhibited a significant elevation $(\mathrm{P}<0.01)$ in total lipid, total cholesterol, triglycerides and LDL cholesterol in all the treated groups throughout the experiment. On the other hand, HDL cholesterol was significantly reduced $(\mathrm{P}<0.01)$ in all groups with low and high doses of BPA for 15 and 30 days.

\section{Histopathological investigations:}

Rat testis- Testis of the control albino rats revealed normal appearance of the seminiferous tubules(Fig.1a) showed various stages of development of the germ cells in the seminiferous tubules. An outer capsule of fibroblastic 
connective tissue bounds the seminiferous tubules followed by basal lamina. Rats treated with BPA in different doses and periods, revealed many pathological changes in the form of hyaline thick capsules together with congested blood vessels (Fig.2a), some seminiferous tubules showed hypocellularly in the spermatogenic cells and desquamation of them. Exudative materials in interstitial space with reduced number of Leyding cells were also detected (Figs. 3, 4\&5a).

Rat Liver-The classic hepatic lobule composed of a central vein and cords of hepatocytes radiating from it with sinusoidal spaces between them. The portal area contained branch of the hepatic portal vein, branch of the hepatic artery and bile ducts. The hepatocytes are observed to be polyhydral cells with eosinophilic cytoplasm. The nuclei of hepatocytes are mostly large with prominent one or more nuclei (Figs.1\&1`b). Liver rats treated with BPA in different doses and periods showed dilated and congested central veins, dilated sinusoids together with increased proliferation of von kupffer cells and lymphocytic infiltration, thickening and hyalinization of some portal veins with haemolysed blood cells in the blood vessels and mild edema and mild inflammatory areas in periportal zoon . (Figs. 2,3\&4b).

Rat Kidney- Microscopic examination of kidney reveled two layers, cortex containing distal convoluted tubules having a wide lumens and proximal ones lined with cuboidal epithelial with brush borders. The medulla comprised loops of Henley and loops of the vasarectae (Fig.1c). Rat groups treated with BPA by different doses and periods, where scattered glomerular tufts showed focal sclerotic changes with hyalinization in some areas, multi interstitial hemorrhagic areas, mild nephritis were seen. Vacuolated tubules, with hyaline casts in their lumens are observed (Figs. $2,3,4 \& 5 c)$.

\section{Discussion:}

Effect of Bisphenol-A on hormonal levels: Prolactin (PRL)- As reveled from the data obtained, BPA in two dose levels caused hyperprolactinemia which is progressively increased with time of the experiment that reached 30 days. Similar data were obtained by Rosemary et al. [21] who stated that BPA as estrogen like effect mimicked estradiol in inducing hyperprolactinemia in an estrogen-sensitive rat. The mechanism may indicate that BPA can induce hyperprolactinemia which alter estrogen receptor and/or estrogen-responsive genes that affect the lactotrophs in rats [22]. Also, Bo Lü and Zhan [23] showed that the blood serum hormone levels of parental female rats were altered by BPA exposure. The PRL and $\mathrm{E}_{2}$ levels of blood serum of BPA group were markedly increased. BPA may simulate estrogen to increase the level of serum PRL, because estrogen has a direct role in stimulating PRL gene expression. In the present study It was found that BPA induced a significant elevation in FSH with concomitant reduction in LH levels with the two dose levels used. Differences in the response of FSH and LH to BPA could be due to differential sensitivity of the systems regulating FSH\& LH secretion to BPA at the level of the pituitary or the hypothalamus [24]. However, Funabashi et al. [25] suggested that BPA could have hypothalamic actions and can alter levels of progesterone receptor expression within the medio-basal hypothalamus. This induced changes in neural systems that could impact upon gonadotrophin secretion.

Testosterone $(\mathbf{T})$ : the present data revealed that serum testosterone level recorded a significant decrease after treatment with BPA. This is in agreement with the results of Akingbemi $\boldsymbol{e t}$ al. [26] and Benson et al.[27] where they reported that BPA has adverse effects on testicular function by decreasing pituitary LH secretion and reducing Leydig cells steroidogenesis. Decreased Leydig cells was compared with the decreased serum LH and $\mathrm{T}$ levels as well as Leydig cell androgen biosynthetic capacity. So, BPA suppressed $\mathrm{T}$ production via decreased LH secretion. There is also evidence that BPA interferes with LH receptor-legend binding.

Our data revealed that BPA at $10-30 \mathrm{mg} / \mathrm{kg} /$ day increased ALAT, ASAT and ALP activities in all groups after 15 and 30 days of treatment.

BPA may have estrogen mimetic activity and can be cytotoxic. The metabolites of its toxicity were detected and characterized for the time in mammals namely isopropyl-hydroxyphenol produced by the cleavage of BPA, Bisphenol-A glutathione conjugate, glutathiony-phenol, glutathionycl 4-isoproplyl-phenol and BPA dimmers. Most of these metabolites apparently share a common metabolic pathway for which considerable evidence of the production of a reactive intermediate helps to explain BPA cytoxicity [28].

Hirokilnoue et al. [29] demonstrated that toxic substances which are accumulated in liver, generated from BPA can induce toxicity in liver. However, BPA glucuronide was excreted into tha bile where the glucuronide was absorbed and 
transported in great amounts into the serosal side of the colon. The large amount of BPA glucuronide excreted into the intestinal tract would also be absorbed into the colon. Also, some of the conjugated BPA is catalyzed by the lumen bacterial B-glucuronidase ,meanwhile BPA would eventually be reabsorbed into the intestine[30] .

Kidney function - The results of this study demonstrated that treatment of male rats with BPA in two doses for two periods induced highly significant increase in serum urea and creatinine.

Korkmaz[31] investigated that bisphenol-A (BPA), nonylphenol (NP), and octylphenol (OP) induced oxidative stress on the kidney tissue of male rats, and co administration of vitamin $\mathrm{C}$, an antioxidant, can prevent any possible oxidative stress.

Protein profile: the present results showed that treatment with BPA in low and high doses throughout the experiment induced highly significant reduction in total proteins and albumin. The liver is the main site of the conjugation and detoxification of drugs and other foreign substances [32]. The hypoproteineamia observed in the present results revealed the hepatotoxic nature of BPA in liver cells. The synthesis of albumin is depressed in a varity of diseases particularly those of the liver. The plasma of patients with liver disease often shows a decrease in the ratio of albumin to globulins (A/G ratio) [33].

BPA, M.P. and Digoxin can cause toxicity and inflammation of liver which induce a significant decrease in protein profile. Hanioka $\boldsymbol{e t}$ al.[34] reported that BPA induced significant reduction in protein liver in rat liver microsomes.

Lipid profile

The results of this study revealed a significant increase in serum total lipid, total cholesterol, triglyceride and LDL cholesterol with concomitant reduction of HDL cholesterol in all the treated groups with BPA in the two dose levers. These compounds can induce estrogenic activity where estrogens have a significant effect on plasma cholesterol. The effect on cholesterol is probably due to an action of the hormone on the lipoproteins associated with cholesterol in the circulation. The higher estrogen like effect of BPA may be the reason for the incidence of myocardial infarction and other complications of arteriosclerotic vascular diseases [35].

Also, it was found that treatment of bisphenol-A increased serum total lipid in rabbits after 12 weeks of intravenous injection. Triglycerides and total cholesterol were increased. The increase in plasma cholesterol caused by
bisphenol-A was apparent for the lipoproteins VLDL and LDL, but not for HDL [36].

Histological examination-The tested compound is endocrine disruptors (EDS) as revealed from the biochemical investigations. Increased level of prolactin hormone can induce infertility which mediate breast enlargement [37]. The increased level of FSH can affect the Sertoli cells which found in the basement membrane of the somniferous tubules and provide the environment necessary for germ cell differentiation and maturation of testis tissues [38]. Decreased lever in LH hormone can reduce Leydig cell steroidogenesis. Leydig cells (interstitial) cells are scattered in the connective tissue between the coiled somniferous tubules which produce testosterone in response to $\mathrm{LH}$, so, testosterone hormone level can be lowered [27].

Since the tested compound is endocrine disruptors, it induced oxidative stress in testis, liver and kidney [39]. Oxidative stress influenced by excess reactive oxygen species (ROS) produced in mitochondria and microcosms are known to damage nucleic acid, lipid and proteins [40]. This can lead to various diseases, including cancer, infertility and neuro-degenerative diseases [41\&42]).

BPA is metabolized in liver and eliminated through the kidney. So the congestion in blood vessels and degenerated tissues of testis, liver and kidney were noticed [28]. Also, Korkmaz [31] demonstrated that histopathological examination of the kidneys of rats in BPA groups revealed necrotic lesions, congestion and mononuclear cell infiltration. These results are in accordance with the present results.

\section{References:}

1-Watson CS, Jeng YJ and Kochukov MY (2010): Nongenomic signaling pathways of estrogen toxicity. Toxicol, Sci ., 115:1-11.

2-Alonso MP, Laribi O, Ropero AB, et al. (2005): Low doses of bisphenol- A and diethylstilbestrol impair $\mathrm{Ca} 2+$ signals in pancreatic alpha-cells through a nonclassical membrane oestrogen receptor within intact islets of Langerhans. Environ. Health Perspect., 113:969-977.

3-Suzuki T, Mizuo K, Nakazawa H, et al., (2003): Prenatal and neonatal exposure to bisphenol-A enhances the central dopamine D1 receptor-mediated action in mice: enhancement of the methamphetamine-induced abuse state. Environ. Health Perspect., 117(12): 1945-1952.

4-Takayanagi S, Tokunaga T, Liu X, et al.,(2006): Endocrine disruptor bisphenol A strongly binds to human estrogen-related receptor gamma (ERRgamma) 
with high constitutive activity. Toxicol. Lett. 167(2):95105.

5-Schecter A , Malik N, Haffner D et al., (2010): Bisphenol A (BPA) in US food. Environ. Sci. Technol.,44 (24): 9425-9430.

6-Reeves P G, Nielsen F H and Fahey G C. (1993): Ain-93 penfield diet or laboratory rodents. Nutr., 123:1939-1951

7-Liu MY and Zhous T T (1994): Radio receptor assay for human prolactin and the heterogeneity of prolactin in the sera form patients with pituitary prolactin-secreting adenoma. Chin .J. Pathophysiol., 10:420-429.

8-Urban RJ, Evans WS, Rogol AD, et al., (1988): Contemporaey aspects of discrete peak-detection algorithms. 1. The paradigm of the luteinizing hormone plus signal in man. Endcor. Rev., 9:33-37.

9-Levine JE, Norman RL, Gliessman PM et al., (1985): In vivo gonadotrophin-reasing hormone release and serum luteinizing hormone measurements in ovariectomized, estrogen-treated rhesus macaques. Endocrinology, 11:707-721.

10-Bricaie C, Raynaud A and Benotmane A (1991): selective venous catheterization in the evaluation of hyperandrenism. J. Endocrinol Invest., 14: 949-956.

11-Reitman, S. and Frankel, S. (1957): Colourimetric method for the vitro determination of GoT and GPt in serum or plasma . Am. J. Clin. Path., 28: 56-63.

12-Jones DB (1982): Clinical Laboratory Methods. C.V.Mosby Co., USA, $9^{\text {th }}$ Ed. P.580-581.

13-Patton C.J. and Crouch, S.R. (1977) Enzymatic determination of urea (according to the urease modified Berthelot reaction). Anal. Chem., 49:464-469.

14-Tietz N W. (1986): Textbook of Clinical Chemistry. WB Saunders, Philadelphia, pp1271-1281.

15-Tietz N W( 1994): Fundamentals of Clinical Chemistry. 2nd Edn., NW Tietz, USA.

16-Kaplan A (1984): Quantitative Determination of Total Tipids. Clin. Chem. The C.V. Mosby Co.St Louis. Toronto. p. 919.

17-Henry RJ, Cannon DC and Winkelman JW (1997): Clinical Chemistry Principles and Tetchiness, Harper and Row. New York, pp: 1440.

18-Fossati $P$ and Principe L. (1982): Serum triglycerides determined calorimetrically with an enzyme that produces hydrogen peroxide. Clinical Chem., 28: 2077-2080.

19-Burstein M (1970): Rapid method for Isolation of lipoproteins form human serum by precipitation with poly-anion. Journal of lipid research, 11:583-583.

20-Drury RA and Wallington E A (1980): Carlton's Histological Techniques,Oxford University Press, New York. pp: 206:225.

21-Rosmary, Steinmetz, Nancy G, et al., (1997): The environmental estrogen Bisphenol-A stimulates prolactin release in vivo and in vitro. Endocrinology, 138: 1780-1786

22-Kuiper GG, Carlsson B, Grandien K et al. (1998): Comparison of the legend binding specificity and transcript tissue distribution of estrogen receptors alpha and beta. Endocrinology. 138(3):863-870.

23-Bo Lü and Ping Zhan (2010): The effects of bisphenol A on sex hormone levels of F0 female rats and F1 male rats during weaning period. Toxicological and Environmental Chemistry, 92 :1729-1733.

24-Neill SJ, Desikan R and Hancock JT (2003): Nitric oxide signalling in plants. New Phytologist, 159:11-35.

25-Funabashi T, Sano A, Mitsushima D and Kimura F (2003): Bisphenol-A increases progesterone receptor immunoreactivity in the hypothalamus in a dose dependent manner and affects sexual behavior in adult ovaricectomised rats. J. Neuroendocrinol., 15:134-140.

26-Akingbemi BT, Ge R, Rosenfeld CS, et al. (2003): Estrogen receptor-a gene deficiency enhances androgen biosynthesis in the mouse Leydig cell. Endoccrinology, 144:84-93.

27-Benson T, Akingenl C M, Sortas A K G, et al. (2004): Inhibition of testicular sterodio- genesis by the xenoestrogen Bisphenol-A associated with reduced pituitary luteinizing hormone secretion and decreased steroidgenic enzyme gene expression in Rat Leydig cells. Endocrinology, 145(2): 592-603.

28-Jaeg JP, Perdu E, Dolol DL et al. (2004): Characterization of new Bisphenol-A metabolites produced by CDI mice liver microsome and 59 fractions. American Chemical Society, 15: 2638. 2645.

29-Hirokilnoue, Hiroshi Y, Tsunehisa M et al. (2001): Bisphenol-A Glucuronide, a Major Metabolite in rat bile after liver perfusion. Drug Metabolism and Disposition, 29:1084-1087.

30-Inoue H, Yokota H, Taniyama H et al., (1999): 1Naphthol B-D-glucuronide formed interaluminally in rat small intestine mucosa and absorbed into the colon .Life Sci., 65:1579-1588.

31- Korkmaz A, Aydoğan M, Kolankaya D and Barlas N(2011):Vitamin C coadministration augments bisphenol A, nonylphenol, and octylphenol induced oxidative damage on kidney of rats. Environmental Toxicology, 26( 4) : 325-337.

32-Segre EJ. (1975): Naproxen metabolism in man. J.Clin. pharmacol., 15:316.

33-Robert K, Daryl KG, Peter A et al., (2000): Hormones of the Gonads. Harper Biochemistry , 25 ${ }^{\text {th }}$ edition. Appleton and Lange Publishers, USA.

34-Hanioka N, Jinno H, Nishmura T and Ando M (1998): Suppression of male-specific cytocrome p 450 isoforms by Bisphenol-A in ret liver. Archives of Toxicology, 72(7):387-394.

35-Ganong W F (1997): Review of Medical Physiology, $17^{\text {th }}$ edition, Sanfransisco-Kalifornia. Appleton and Hange, Norwalk C T, pp. 459-490.

36-Paul K, Annmargret OL, Christer W et al., (1999): Dissociation of athrogenesis from aortic accumulation of lipid pero-oxides in watanabe heritable hyperlipidemic rabbits. J. Clin. Invest., 104(2): 213-220. 37-Genissel C Carreaus (2001): Regulation of the aromatase gene expression in mature rat leydig cells. Mol Cell Endocrinol., 178:141-146. 
38-Sweeney T, Nicol L, Roche JF and Brooks AN (2000): Maternal exposure to octylphenol suppresses ovine fetal follicle stimulating hormone secretion, testis size and sertoli cell number. Endocrinology,141:26672673.

39-Bindhumol V, Chitre $\mathrm{K} \mathbf{C}$ and Mathur $\mathbf{P} \mathbf{P}$ (2003): Bisphenol- A induces reactive oxygen species generation in the liver of male rats. Toxicology, 188:117-124.

40-Chitra K C, Latchoumycandane $C$ and Mathur PP (2003): Induction of oxidative stress by Bisphenol-
A in the epididymal sperm of rats. Toxicology, 14:119127.

41-Kabuto H, Amaklawa $M$ and Shishibori T (2004): Exposure to Bisphenol-A dying embryonic fetal life and reactive oxygen species in mouse tissues. Environ. Res., 93:31-35.

42-Zhong L, Shimoji M, Thomas B and et al., (2005): Mitochondrial localization of the Parkinson disease related protein DJ-L: Implications for pathogenesis. Hum. Mol. Genet., 14:2063-2073.

Table (1) - The effect of low and high doses of bisphenol-A on certain hormonal levels in male albino rats.

\begin{tabular}{|c|c|c|c|c|c|c|c|c|c|}
\hline groups & Days & PRL ng/ml & $\begin{array}{l}\% \text { of } \\
\text { changes }\end{array}$ & FSH $\mathrm{ml} \mathrm{U} / \mathrm{ml}$ & $\begin{array}{l}\% \text { of } \\
\text { change }\end{array}$ & $\mathrm{LH} \mathrm{mlU} / \mathrm{ml}$ & $\begin{array}{l}\% \text { of } \\
\text { change }\end{array}$ & $\mathrm{T} \mathrm{ng} / \mathrm{ml}$ & $\begin{array}{l}\% \text { of } \\
\text { change }\end{array}$ \\
\hline $\mathrm{Nc}$ & \multirow{4}{*}{15} & $4.09 \pm 0.244$ & & $1.99 \pm 0.07$ & & $10.9 \pm 0.343$ & & $15.5 \pm 0.188$ & \\
\hline $\mathrm{PC}$ & & $4.2 \pm 0.199$ & $3 \%$ & $1.87 \pm 0.108$ & $6 \%$ & $9.79 \pm 0.141$ & $-10 \%$ & $14.5 \pm 0.33$ & $-6 \%$ \\
\hline BPAL & & $7.1 \pm 0.167$ ** & $74 \%$ & $\begin{array}{l}5.53 \pm 0.104 \\
* *\end{array}$ & $178 \%$ & $7.7 \pm 0.157^{* *}$ & $-29 \%$ & $13.9 \pm 0.029 * *$ & $-103 \%$ \\
\hline BPAH & & $10.7 \pm 0.31 * *$ & $162 \%$ & $7.47 \pm 0.128 * *$ & $275 \%$ & $5.65 \pm 0.128 * *$ & $-48 \%$ & $11.48 \pm 0.21 * *$ & $26 \%$ \\
\hline $\mathrm{NC}$ & \multirow{4}{*}{30} & $4.6 \pm 0.197$ & & $2.02 \pm 0.08$ & & $11.07 \pm 0.28$ & & $15.2 \pm 0.54$ & \\
\hline $\mathrm{PC}$ & & $4.2 \pm 0.209$ & $9 \%$ & $1.9 \pm 0.34$ & $6 \%$ & $10 \pm 0.25$ & $-9.6 \%$ & $15.7 \pm 0.309$ & $3.3 \%$ \\
\hline BPAL & & $11.3 \pm 0.55^{* *}$ & $146 \%$ & $6.56 \pm 0.16^{* *}$ & $224 \%$ & $5.89 \pm 0.219 * *$ & $-47 \%$ & $12.5 \pm 0.403 * *$ & $-18 \%$ \\
\hline BPAH & & $20.05 \pm 0.14 * *$ & $336 \%$ & $9.27 \pm 0.124$ & $358 \%$ & $4.21 \pm 0.41^{* *}$ & $-62 \%$ & $8.7 \pm 0.177^{* * *}$ & $-43 \%$ \\
\hline
\end{tabular}

Values are statistically significant at $* \mathrm{P}<0.05, * * \mathrm{P}<0.01$, (N.S) Non-Significant.

Table (2) - The effect of low and high doses of bisphenol-A on serum enzymes ALT, AST\&ALP(U/L) activities in male albino rats.

\begin{tabular}{|c|c|c|c|c|c|c|c|}
\hline groups & Days & ALT & $\begin{array}{l}\% \text { of } \\
\text { changes }\end{array}$ & AST & $\begin{array}{l}\% \text { of } \\
\text { change }\end{array}$ & ALP & $\begin{array}{l}\% \text { of } \\
\text { change }\end{array}$ \\
\hline $\mathrm{NC}$ & \multirow{4}{*}{15} & $18 \pm 0.577$ & & $15.3 \pm 0.8$ & & $403.5 \pm 4.02$ & \\
\hline $\mathrm{PC}$ & & $19 \pm 1.07$ & $5.5 \%$ & $15.5 \pm 0.84$ & $1.3 \%$ & $401.15 \pm 3.1$ & $-0.6 \%$ \\
\hline BPAL & & $27.2 \pm 0.601 * *$ & $51 \%$ & $25.7 \pm 0.95 * *$ & $68 \%$ & $517.5 \pm 2.5 * *$ & $0.28 \%$ \\
\hline BPAH & & $56.7 \pm 1.453 * *$ & $215 \%$ & $41.83 \pm 1.64 * *$ & $173 \%$ & $639.03 \pm 4.6^{* *}$ & $58 \%$ \\
\hline $\mathrm{NC}$ & \multirow{4}{*}{30} & $18.8 \pm 0.87$ & & $16.3 \pm 0.67$ & & $401.1 \pm 2.8$ & \\
\hline $\mathrm{PC}$ & & $19.16 \pm 0.6$ & $1.9 \%$ & $15.8 \pm 1.13$ & $-3.1 \%$ & $405.5 \pm 3.6$ & $1.09 \%$ \\
\hline BPAL & & $54.2 \pm 2.358 * *$ & $188 \%$ & $52 \pm 1.9 * *$ & $219 \%$ & $700 \pm 2 * *$ & $74.5 \%$ \\
\hline$\overline{\mathrm{BPAH}}$ & & $79.8 \pm 1.30 * *$ & $324 \%$ & $87.3 \pm 2.78 * *$ & $435 \%$ & $801 \pm 3.2 * *$ & $99 \%$ \\
\hline
\end{tabular}

Values are statistically significant at $* \mathrm{P}<0.05, * * \mathrm{P}<0.01$, (N.S) Non-Significant. 
Table (3) - The effect of low and high doses of bisphenol-A on kidney function in male albino rats.

\begin{tabular}{|c|c|c|c|c|c|}
\hline groups & Days & Urea $\mathrm{mg} / \mathrm{dl}$ & $\begin{array}{l}\% \text { of } \\
\text { changes }\end{array}$ & $\begin{array}{l}\text { Creatinine } \\
\mathrm{mg} / \mathrm{dl}\end{array}$ & $\%$ of change \\
\hline $\mathrm{Nc}$ & \multirow{4}{*}{15} & $38.3 \pm 0.91$ & & $0.44 \pm 0.0133$ & \\
\hline $\mathrm{PC}$ & & $37.83 \pm 1.58$ & $-1.2 \%$ & $0.47 \pm 0.015$ & $8 \%$ \\
\hline BPAL & & $53.95 \pm 1.58 * *$ & $40 \%$ & $0.53 \pm 0.181 * *$ & $22 \%$ \\
\hline BPAH & & $73.15 \pm 1.79 * *$ & $91 \%$ & $0.68 \pm 0.021 * *$ & $55 \%$ \\
\hline $\mathrm{NC}$ & \multirow{4}{*}{30} & $40.8 \pm 1.39$ & & $0.43 \pm 0.018$ & \\
\hline $\mathrm{PC}$ & & $38 \pm 2.02$ & $-7 \%$ & $0.49 \pm 0.012$ & $15 \%$ \\
\hline BPAL & & $61.4 \pm 0.988 * *$ & $50 \%$ & $0.60 \pm 0.011 * *$ & $40 \%$ \\
\hline BPAH & & $82.6 \pm 1.35^{* *}$ & $102 \%$ & $0.83 \pm 0.017 * *$ & $95 \%$ \\
\hline
\end{tabular}

Values are statistically significant at $* \mathrm{P}<0.05, * * \mathrm{P}<0.01$, (N.S) Non-Significant.

Results: Table (4) - The effect of low and high doses of bisphenol-A on serum total protein\& A/G ratio (g/dl) in male albino rats.

\begin{tabular}{|c|c|c|c|c|c|c|c|c|c|}
\hline groups & Days & $\begin{array}{l}\text { Total } \\
\text { protein }\end{array}$ & $\begin{array}{l}\% \text { of } \\
\text { changes }\end{array}$ & Albumin & $\begin{array}{l}\% \text { of } \\
\text { change }\end{array}$ & Globulin & $\begin{array}{l}\% \text { of } \\
\text { change }\end{array}$ & $\mathrm{A} / \mathrm{G}$ ratio & $\begin{array}{l}\% \text { of } \\
\text { change }\end{array}$ \\
\hline $\mathrm{Nc}$ & \multirow{4}{*}{15} & $8.3 \pm 0.07$ & & $5.2 \pm 0.05$ & & $3.1 \pm 0.12$ & & $1.67 \pm 0.05$ & \\
\hline $\mathrm{PC}$ & & $8.2 \pm 0.07$ & $-1.2 \%$ & $5.1 \pm 0.05$ & $-1.9 \%$ & $3.1 \pm 0.07$ & $0 \%$ & $1.66 \pm 0.049$ & $-0.66 \%$ \\
\hline BPAL & & $7.1 \pm 0.17 * *$ & $-14 \%$ & $4.08 \pm 0.07 * *$ & $-21 \%$ & $\begin{array}{l}301 \pm 0.17 \\
\text { NS }\end{array}$ & $0 \%$ & $1.3 \pm 0.09 *$ & $-22 \%$ \\
\hline BPAH & & $6.05 \pm 0.16^{* *}$ & $-27 \%$ & $3.1 \pm 0.03 * *$ & $-40 \%$ & $\begin{array}{l}2.96 \pm 0.18 \\
\text { NS }\end{array}$ & $-4.5 \%$ & $1.04 \pm 0.06^{* *}$ & $-37 \%$ \\
\hline $\mathrm{NC}$ & \multirow{4}{*}{30} & $8.2 \pm 0.09$ & & $5.13 \pm 0.07$ & & $3.1 \pm 0.08$ & & $1.64 \pm 0.05$ & \\
\hline $\mathrm{PC}$ & & $8.15 \pm 0.11$ & $-1.2 \%$ & $5.1 \pm 0.068$ & $-0.58 \%$ & $3.05 \pm 0.05$ & $-1.6 \%$ & $1.67 \pm 0.02$ & $1.8 \%$ \\
\hline BPAL & & $6.13 \pm 0.12 * *$ & $-25 \%$ & $3 \pm 0.05 * *$ & $-41 \%$ & $\begin{array}{l}3.13 \pm 0.10 \\
\mathrm{NS}\end{array}$ & $0.96 \%$ & $0.96 \pm 0.04 * *$ & $-41 \%$ \\
\hline BPAH & & $5.7 \pm 0.16^{* *}$ & $-31 \%$ & $2.5 \pm 0.1 * *$ & $-53 \%$ & $\begin{array}{l}3.3 \pm 0.14 \\
\mathrm{NS}\end{array}$ & $0 \%$ & $0.73 \pm 0.05 * *$ & $-55 \%$ \\
\hline
\end{tabular}

Values are statistically significant at $* \mathrm{P}<0.05, * * \mathrm{P}<0.01$, (N.S) Non-Significant. 


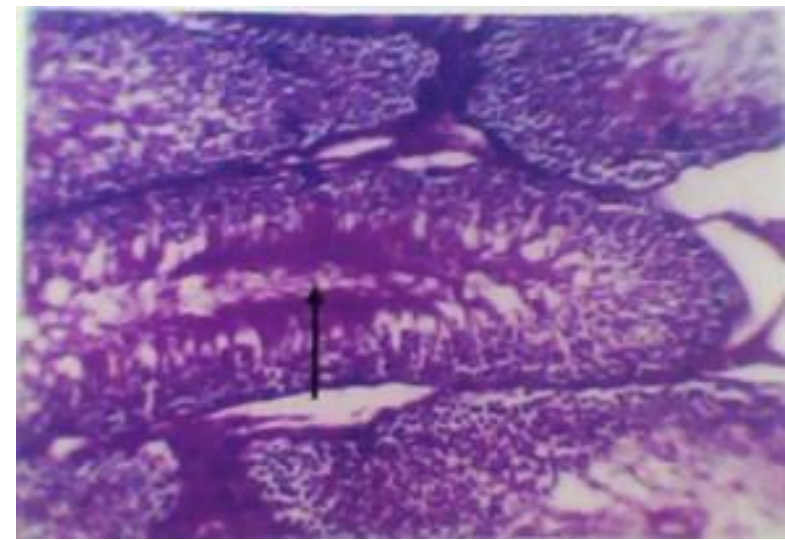

Fig.(1a) Photomicrograph of testis tissue of control rat revealed normal appearance of seminiferous tubules with sperms in the lumen (arrow) (H\&E,x:200)

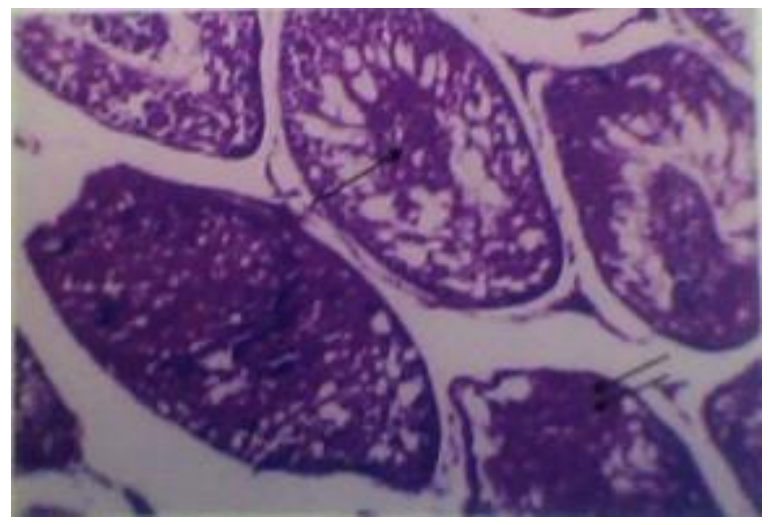

Fig. (3a) Photomicrograph of testis tissue of a rat with BPA showing desquamated cells in the lumen of some interstitial space , seminiferous tubules, hyaline desposition in other seminiferous vacuolation in some seminiferous tubules. (H\&E,x200)

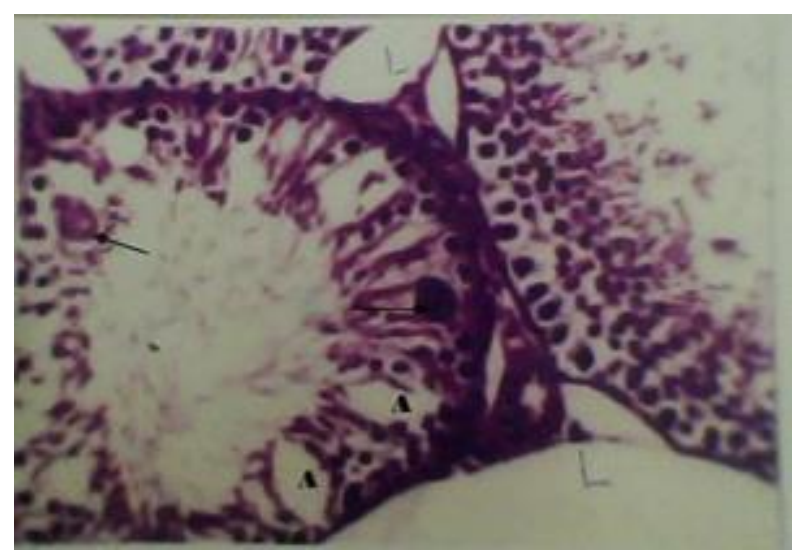

Fig. (5a) Photomicrograph of testis tissue of a rat treated with BPA showing remnants of the degenerated sperms in the lumen of the seminiferous tubules with hypocellularity in them, gaint cells and highly reduced Leydig cells.(H\&Ex200)

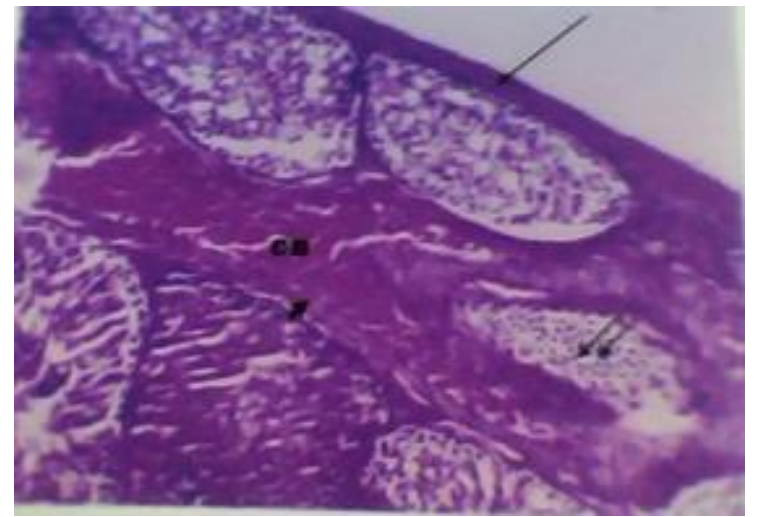

Fig. (2a) Photomicrograph of testis tissue of a rat treated with BpA showing thick capsule, (arrow head) congested blood vessel and seminiferous tubules with arested spermatogenesis . (Double arrows) (H\&E,x:200)

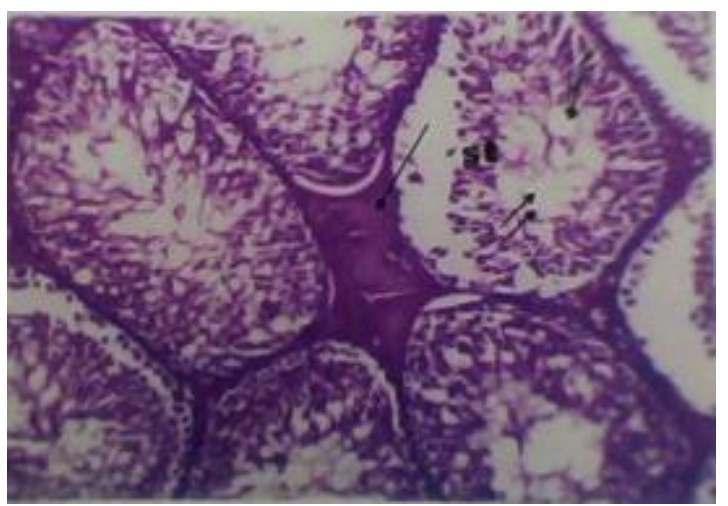

Fig. (4a) Photomicrograph of testis tissue of a rats treated BDA displaying hylinzation or exudative in the tubules which extend to the basal membrane (H\&E,X200)

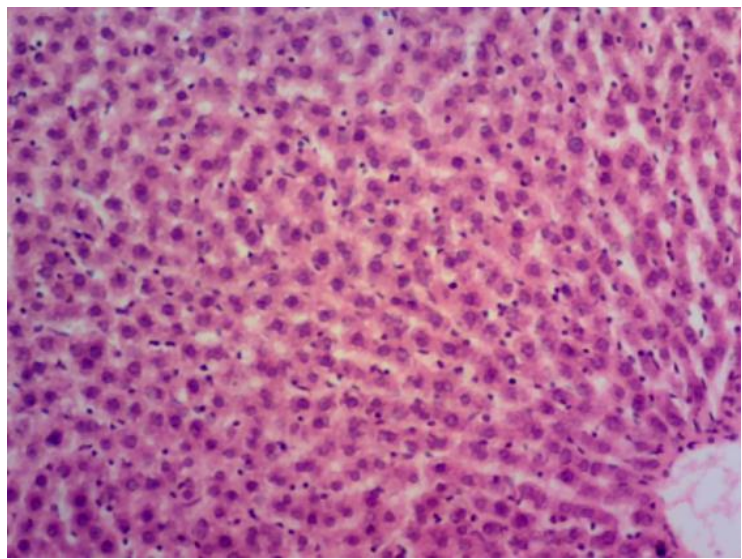

Fig. (1b) Photomicrograph of liver tissue of the control group, showing central vein $(\mathrm{CV})$, intact hepatocyte arranged in cords (H\&E,x200). 


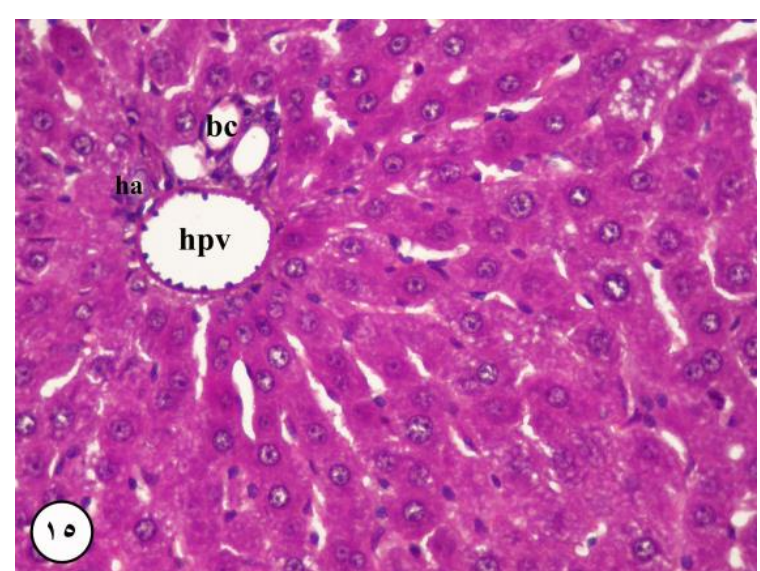

Fig. (1b'): Photomicrograph of liver tissue of control group, showing hepatic portal vein (hpv), intact hepatocyte arranged in cords, branch of the hepatic artery and bile ducts (H\&E,x200).

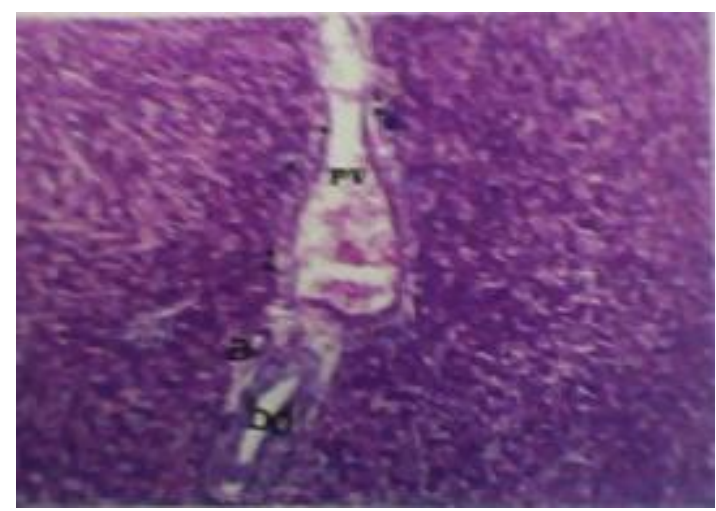

Fig. (3b) Photomicrograph of liver tissue of a rat treated with BPA showing highly dilated, elongated and corrugated wall of the hepatic portal vein (PV), which contains haemolysed blood cells highly proliferated walls of the bile duct (bd), thickned arterial wall (a), lymphocytic infiltration around the portal vei with hypertrophied hepatocytes(H\&E,x200).

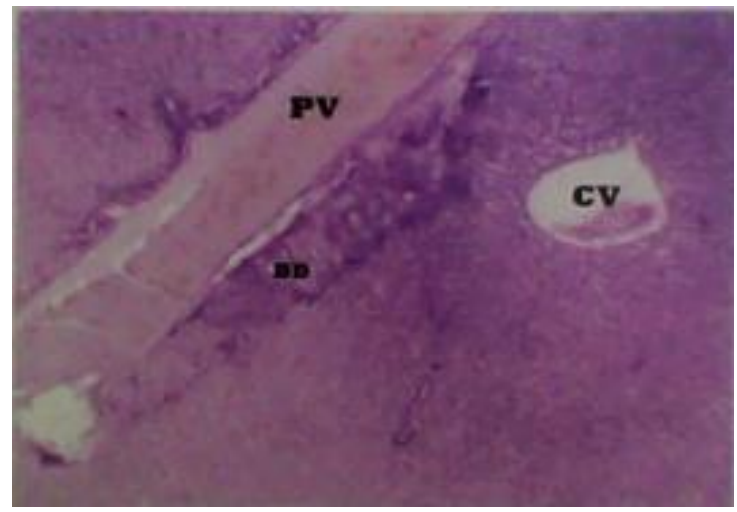

Fig. (5b): Photomicrograph of liver tissue of rat treated with BPA showing highly elongated hepaticportal vein (pv) and central vein (cv) contain haemolysed blood cells, highly proliferated bill duct (BD) with obstructed lumen

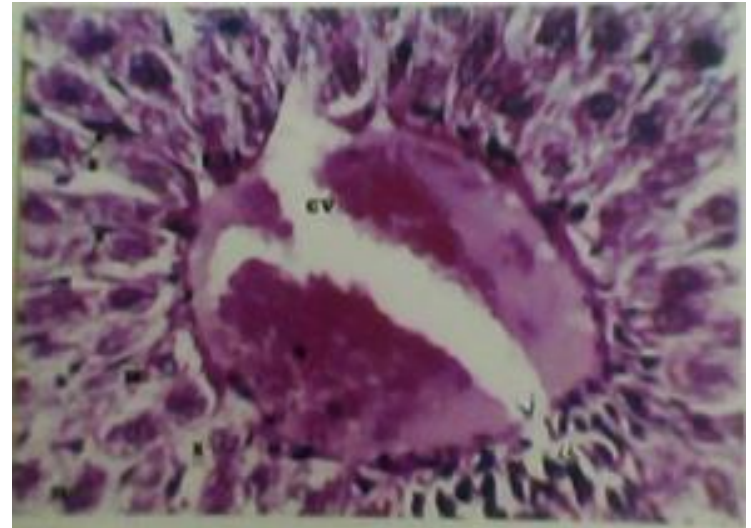

Fig. (2b) Photomicrograph of liver tissue of a rat treated with BPA showing highly dilated and congested central vein $(\mathrm{CV})$ with ruptured wall, it contains haemolysed blood cells, dilated sinusoidal spaces (S), hypertrophied hepatocutes, some of them contained pyknotic nuclei and cytoplasmic vacuolation (H\&E,x200).

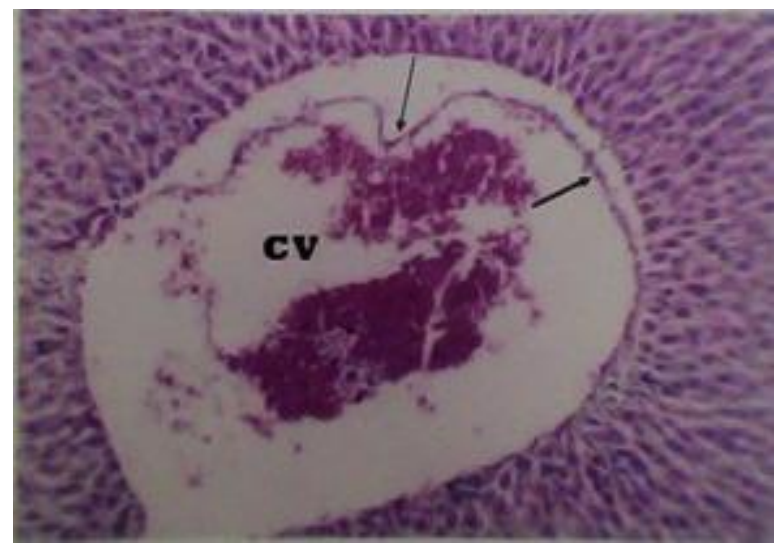

Fig. (4b) Photomicrograph of liver tissue of rat treated with BPA showing highly dilated central vein (cv) delaminated endothelial lining of it. It contains debris of haemolysed blood cells with lymphocytic infiltration around it. (H\&E x300).

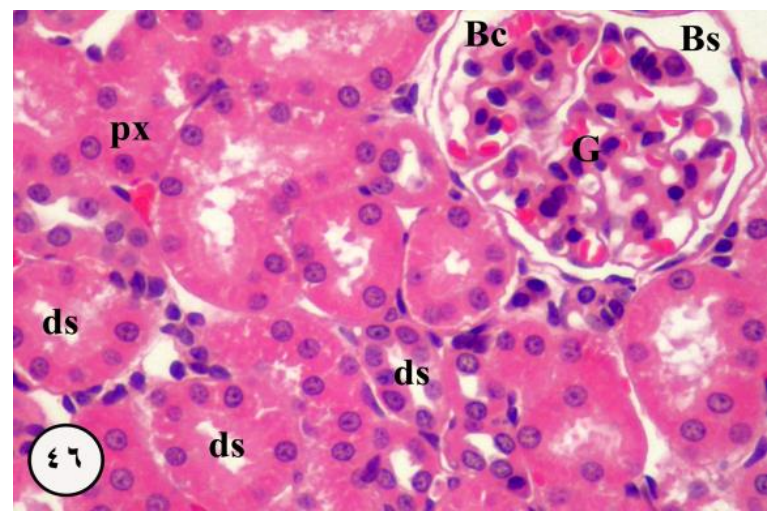

Fig. (1c): Photomicrograph of kidney tissue of control albino rats showing normal glomerular tufts $(\mathrm{g})$, proximal convoluted tubules $(\mathrm{Px})$, distal tubules(ds).(H\&Ex200) 


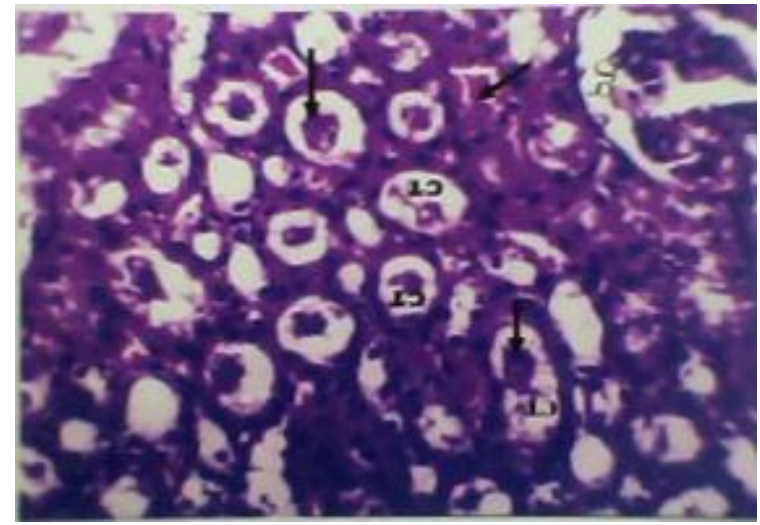

Fig. (2c) Photomicrograph of kidney tissue of a rat treated with BPA showing hyaline casts (Arrow), in some convoluted tubules (CT) cells with lobulated glomerules (G). (H\&E x200).

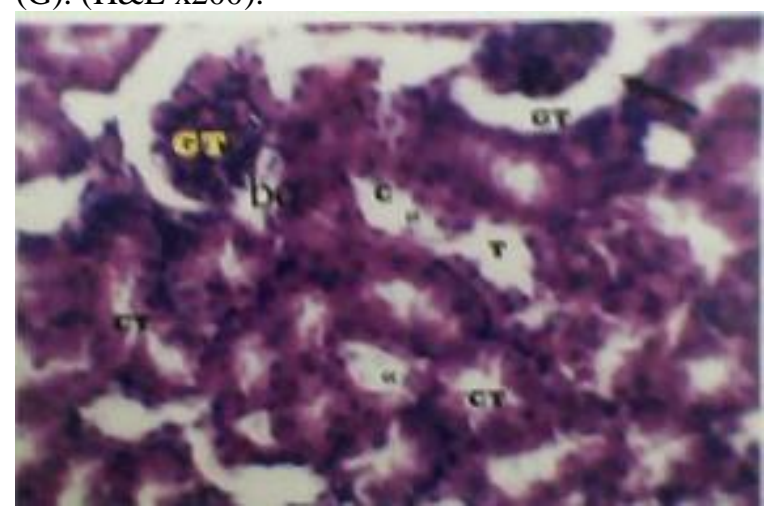

Fig. (4c): Photomicrograph of kidney tissue of rat treated with BPA showing pykrotic nuclei inside the glomeruli (GT) with highly widened Bowman s space, ruptured Bowman s capsules (bc), dilated lumens of the distal convoluted lubules (ct) with debris of degenerated cells in them. (H\&E x200).

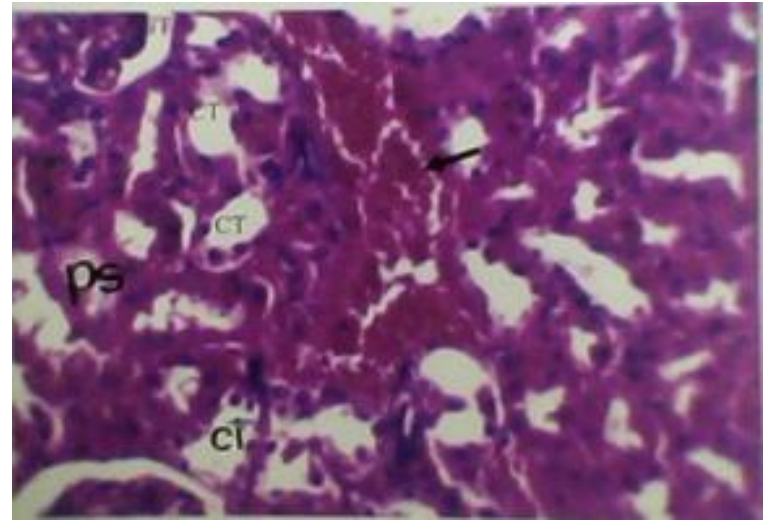

Fig. (3c) Photomicrograph of kidney tissue of rat treated with BPA showing large intertubular haemorrhogic area (Arrow), highly distorted distal convoluted tubules (CT) and proximal ones (ps)). (H\&E x200)

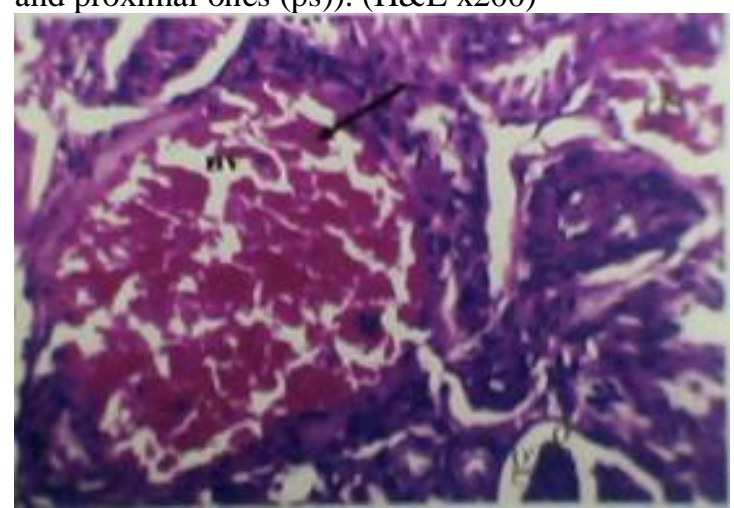

Fig. (5c): Photomicrograph of kidney tissue of a rat treated with BPA showing dilated and congested blood vessel (arrow), interstitial haemorrhagic area, lobulated glomerulus (g), highly distorted distal convoluted. (H\&E x200). 